\title{
Hayali Evrenler: Kadın Kahramanın Fantastik Yolculuğu
}

\author{
Övünç Ege*
}

\section{Özet}

Toplumların inançları ve günlük yaşam pratiklerini anlatan mitler toplumlarn ve bireyleri dolayısıyla da kolektif bilinç ve kolektif bilinçdışını yansıtır. Dış dünyayı anlatan bu mitlerin eril bir şekilde kodlanması kadın ve erkeğin toplumsal olarak konumlandınlmasıyla ilgilidir. Antik mitler çoğunlukla erkek kahramanları konu alırken "modern mitler" ve bu mitlerin üreticilerinden birisi olan sinema, erkek kahramanın yam sıra kadın kahramanı da konu almaktadır. Yola çıkan kadın kahraman yolculuğu sırasında bir takım dönüşümler geçirir. Geçirdiği bu dönüşümler "erkeğin dünyası" olarak görülen dış dünyada kadının varlı̆̆ını kanıtlama çabası olarak da görülebilir. Kadın kahramanın çıktığı fantastik yolculuk ve bu yolculukta karşısına çıkan karakterler, olaylar, durumlar ve engeller aslında kadın kahramanın bilinçdışının bir yansımasıdır. Bu yansımanın belirli bir şablon izlediği görüşü de monomit kuramının çıkış fikrini ortaya koyar. Bu nedenle çalışmada Campbell'ın ortaya attığı multidisipliner bir kuram olan ve erkek kahramanın yolculuğunu anlatan monomit kuramının kadın kahramana uyarlanmış hali olan Maureen Murdock'ın kadın kahramanın yolculuğu şeması izlenmiştir. Bu şema sayesinde kadın kahramanın yaşadığı dönüşümler daha net bir şekilde görülebilmiştir. Baskıcı rejimin etkin rol oynadığı ve kadın kahramanın tek başına fantastik bir yolculuğa çıtı̆̆ğ filmler olan; Valerie a Týden Divu (Valerie ve Harikalar Haftasl, Jaromil Jireš, 1970), El Laberinto del Fauno (Pan'in Labirenti, Guillermo del Toro, 2006) ve Alice in Wonderland (Alice Harikalar Diyarında, Tim Burton, 2010) filmleri çalışmanın örneklemini oluşturmaktadır.

Anahtar kelimeler: monomit, bilinçdışı, mitoloji, kadın kahramanın yolculuğu, fantastik.

*ORCID: 0000-0002-2078-9008

E-Mail: ovunc.ege@gmail.com

DOI: $10.31122 /$ sinefilozofi. 675586

Geliş Tarihi - Recieved: 15.01.2020

Kabul Tarihi - Accepted: 10.05.2020 


\title{
Imaginary Universes: The Heroine's Fantastic Journey
}

\author{
Övünç Ege*
}

\begin{abstract}
Abstarct
Myths, which are traditional stories including the beliefs and practices of daily life of societies, reflect these societies and individuals, and thus collective consciousness and collective unconscious. The masculine tone in coding of these myths describes and reproduces also the social positions of men and women in society. While the ancient myths tell stories where mostly the male heroes are in the center, the female heroes are included in the narratives in the cinema, as one of the producers of "modern myths". In the modern myths, the female protagonist undergoes a series of transformations during her journey. These transformations can be regarded as an attempt to prove the existence of woman in the outer world, which signifies the male's world. The fantastic journey of the female protagonist and the characters, events, situations and obstacles that come across during this journey are actually the reflections of the unconscious of the heroine. The view that these reflections follow a certain pattern also forms the basis of the monomyth theory. In this study, Maureen Murdock's scheme of "the heroine's journey" derived from the monomyth, a multidisciplinary theory formulated by Joseph Campbell, will be followed. In virtue of this scheme, the transformations experienced by the heroine could be seen in a clearer way. From this perspective, in this study, Valerie a Týden Divu (Jaromil Jireš, 1970), El Laberinto del Fauno (Guillermo del Toro, 2006) and Alice in Wonderland (Tim Burton, 2010), in which the oppressive and authoritarian regimes play an active role and where the heroine takes a fantastic journey alone, will be analyzed.
\end{abstract}

Key Words: Monomyth, unconsciousness, mythology, heroine's journey, fantastic.

*ORCID: 0000-0002-2078-9008

E-Mail: ovunc.ege@gmail.com

DOI: $10.31122 /$ sinefilozofi.675586

Received - Geliş Tarihi: 15.01.2020

Accepted - Kabul Tarihi: 10.05.2020 


\section{Giriş}

Bir sektör olarak sinema farklı coğrafyalardaki farklı toplumların geçmişlerinden, bugünlerinden ve gelecek tahayyüllerinden beslenir. $\mathrm{Bu}$ nedenle filmler hem içinde bulundukları toplumu yansitır hem de o toplumu şekillendirir. Martha Wolfenstein, Movie: A Psychological Study'de (aktaran Kabadayı, 2014: 76) sinemanın toplumların düşlerini, mitlerini ve korkularını kristalize ettiğini belirtmektedir. Bu bağlamda sinema ve mitoloji sadece birbirlerini beslemekle kalmazlar. Sinema, modern mitolojinin bir üreticisi olmasının yanı sıra kökenini de mitolojiden alır ve aslında mitolojinin ardılıdır.

Mitoloji sadece antik dönem halklarına ait, onların hikâyelerini anlatan kültürel bir yapı değildir. Mitosları aynı zamanda modern toplumlarda bireylerin günlük yaşam pratiklerine işleyen hikâyeler olarak da görmek gerekir. Mitosların dini otoritelerce değil, tarihçiler tarafından yazıldığı düşünüldü̈̆ünde antik toplumların dini inançlarından çok günlük yaşam pratiklerine 1şık tuttuğu söylenebilir. Bu mitler genellikle bir coğrafyaya ait, üstün özellikleri olan, çoğunlukla "erkek" kahramanın kendisini, ülkesini ya da yönetimindeki insanları kurtarmaya çalışmasını anlatır. Bu kahramanın asıl hedefi ideal toplum düzenini kurmak ya da var olan düzeni (ki bu da kendi hegemonyasıdır) devam ettirmektir. Erkek kahramanın yolculuğunun anlatıldığı bu mitosların sonunda kahraman gücünü kanıtlar ve erkini kuvvetlendirerek vatanına geri döner ya da önce gücünü sonra her şeyini kaybeder. Toplumsal ve kolektif hikâyeler olan mitosların yapılandırılmış olması onları ideolojik birer araç olarak konumlandırabilmemize olanak sağlar. Zaman içerisinde farklı coğrafyalarda ve kültürlerde yayılım göstermesi de egemen söylemin ideolojisini yayan bir propaganda aracı haline gelmelerine neden olur. Erkek kahraman yolculuğu sırasında karşısına çıkan engelleri aşarken aynı zamanda erkeklik inşasını da yapmış olur. Yolculuğunu tamamlayarak başarıya ulaşan erkek (yani egemen olan eril söylem doğrultusunda erkekliğini kanıtlayan erkek) inşa sonucu kurduğu eril hegemonyasını sağlama alır.

Monomit kuramin kurucusu Joseph Campbell'a göre mitoslarda kahraman arketipi de kahramanın yolculuğu da belirli bir kalıp içerisindedir. "Olay ve yer bakımından sonsuz çeşitlik göstermesine karşın, dünya üzerindeki tüm mitoslar aynı kalıbı izler" (Tecimer, 2006: 107). Bu nedenle Campbell, kahramanın yolculuğunu evrensel bir arketip olarak inceler ve bunu yaparken de kadın kahramanların yolculuklarını 1skalar. Çünkü genel mitos kalıbında kahraman erkek, mekân "erkeğin dünyası", zaman da "erkeğin zamanı"dır. Homeros eserlerinde Heroic Age, Hesiodos eserlerinde ise Ages of Man olarak tanımlanan zaman dilimindeki kahramanlar erkektir. Etimolojik olarak eril bir kavrama işaret eden hero (erkek kahraman), yine eril olan ve erkeğin hikâyesini tanımlayan tarihin (his-story) başkahramanıdır. Kadının buradaki konumlandırması ise eril özellik gösteren birkaç örnek dışında tamamen edilgendir. Kadının toplumdaki edilgen konumu mitosları şekillendirirken mitoslardaki kadının edilgen konumu toplumdaki kadının yerini meşrulaştırmaktadır. Bu bağlamı modern mitlerin üreticisi olan sinema üzerinden kurduğumuzda da benzer bir sonuç elde ederiz. Fakat kadının söz konusu bu edilgen durumu zaman içerisinde değişmeye başlamıştır ve bu da "güçlü kadın" imgesi üzerinden yeni kadın temsillerine ihtiyacı doğurmuştur. Bu noktada güçlü kadın imgesinin de eril kodlar üzerinden kurulmuş olması aslında kadının konumunun yine erkeğin üzerinden tanımlandığını gösterse de kavramların anlamlandırılma süreçlerinde yapılması gereken değişimleri de göz önüne sermesi açısından mühimdir. Ortaya çıkan güçlü kadın imgesi Maureen Murdock'ın 
kahramanın yolculuğunu yeniden okumasına kapı açmış ve bu çalışmanın ana eksenini oluşturmuştur.

Birbirine paralel olarak ilerlemeyen iki şema arasındaki ayrım, kadın ve erkeğin biyolojik farklarına referans vermez. Aksine iki şemayı birbirinden ayıran en büyük nokta toplumsal cinsiyet rolleri ve bu rollerin içselleştirilmesidir. Toplumsal cinsiyet kalıpları kültürel olarak şekillenir ve günlük yaşam pratiklerine etki eder. Bu noktada oluşturulan imge -örneğin kadın imgesi- "doğal" değil, kültüreldir ve Berger'in Görme Biçimlerine referansla söylemek gerekirse de bu imgenin altında bir görme biçimi yatar. Görmenin nesnel bir edim değil, sosyo-kültürel bir belirlenim olması ise aslında toplumsal cinsiyetin, ideolojik bakışın bir sonucu olduğunu bizlere gösterir. "Cinsiyetin doğuştan gelen bir özellik olarak kabul görmesi ve bedensel/fizyolojik farklılıklar üzerinden tanımlanması ise doğrudan erkek-egemen söylemin üretildiği ideolojik bir mevzidir" (Özdoyran, 2019: 63). Temsiller üzerinden sağlamlaştırılan bu konumlar da temsilin ideolojik işlevine işaret eder. Bu bağlamda eril söylem bireyi olduğu kadar bakışı da cinsiyetlendirir ve cinsiyetlendirilmiş bakış yöneltildiği birey üzerinde bir tahakküm kurar. Bakışın erilliği biyolojik erkeğe değil, kültürel olarak kodlanmış erkekliğe dayanır. Bu nedenle eril bakış sadece erkekten kadına doğru değil, kadından erkeğe ya da kadından kadına da yöneltilebilir. Tahakkümün içselleştirilmesi ise kadın kahramanın yolculuğunun büyük bir bölümünde karşımıza çıkar. Kadın kahramanın bakışının eril bir şekilde kodlanması aslında kahramanın karşısındaki en büyük engeldir.

Campbell'ın monomit kuramında erkek kahramanın yolculuğu gücünü kazanmaya dolayısıyla da egemenliğini kanıtlamaya yönelik sonuç odaklı bir yolculuktur. Murdock'ın yolculuğa çıkan kadın kahramanları ise yolculuğuna bireyselliğini kazanarak bağımlılığı koparmak ve tek başına var olabileceğini kanıtlamak için çıkar. Kısacası kadın kahraman, kendi yolculuğunda "erkeğin dünyasını" inşa eden eril söyleme ve hegemonik erkekliğe karşı durarak erkeğin adı olmadan da var olabileceğini göstermek ister. Bunu yaparken ilk başta düştüğü eril bakış tuzağından kurtulması gerekir.

Bu çalışmada kadın kahramanın yolculuğu üç farklı coğrafya, dönem ve kültüre ait filmler üzerinden ele alınmıştır. Üç filmde de başroldeki kadın kahramanlar çevrelerindeki baskıcı rejimden kaçmak için oluşturdukları hayali evrenlerde bir yolculuğa çıkmaktadır. Valerie a Týden Divu, Nazi ve Stalin rejimleri arasında sıkışmış Çekoslovakya'da, kültürel kırılma noktalarının yaşandığı bir dönemde dini baskılar içerisinde sıkışan, ergenliğe yeni girmiş Valerie' yi (Jaroslava Schallerová); El Laberinto del Fauno, İç Savaş dönemi sonrasında İspanya'da yıkımı, fakirliği ve ölümü yaşayan bir çocuk olan Ofelia'yı (Ivana Baquero) ve Alice in Wonderland ise kadına yönelik baskının hat safhada olduğu Viktorya Dönemi İngilteresi'nde, evlilik çağındaki Alice'i (Mia Wasikowska) anlatır. Çek Yani Dalga, İspanyol ve Hollywood sinemasına ait olan üç örnekte de kadın kahramanın yolculuğu karşılaştırmalı olarak analiz edilmiştir.

\section{Monomit Ve Kadın Kahramanın Yolculuğu}

Joseph Campbell, The Hero With A Thousand Face (Kahramanın Sonsuz Yolculuğu) kitabında detaylandırdığı monomit kuramını Alman antropolog Adolf Bastian ve analitik psikolojinin kurucusu Carl Gustav Jung'un görüşlerini sentezleyerek oluşturmuştur. Bu yolculuk farklı coğrafyalardaki farklı kültürlerin mitoslarını analiz etme açısından önemlidir. 
Fakat Campbell kahramanın kendisini ve yolculuğunu evrensel bir arketip olarak ele alırken kadın kahramanın yolculuğunu iskalamaktadır. Monomite göre ortada tek bir mit vardır ve bu mit erkek kahramanın hikâyesini anlatır. Bunun sebebi ise dilin, dolayısıyla da dil tarafından oluşturulan mitolojinin eril yapısıdır. Eril olarak yapılanan dil, kendi söylemi olan eril söylemi yeniden üretir. Mitlerde gördüğümüz az sayıdaki kadın kahraman da aslında maskülen özellikleri ile bu söylemin yeniden üretilmesine imkân sağlar. Kadınlar, kadına atfedilen geleneksel özelliklerinden arınmış; güçlü olma, cesur olma, savaşçı olma ve kurtarıcı olma gibi erkeğe atfedilmiş özellikler ile bütünleşmiş kahramanlar olarak; aslında birer "erkek" olarak karşımıza çıkarlar. Bu nokta kadın ve erkek kahramanın yolculuğunun en büyük ayrımlarından birisidir. Çünkü eril söylem kadın tarafından o kadar içselleştirilmiştir ki yolunda başarılı olabilmek için ilk olarak feminen olarak tanımlanan geleneksel kadın özelliklerinden feragat etmesi gerektiğini düşünür.

Mitosların dönemin erk sahibi kişilerince yazdırılmış, bu kişiler tarafından kendi görüşleri ile şekillendirilmiş ideolojik hikâyeler olduğunu iddia etmek yanlış olmayacaktır. Bu bağlamda günümüze ulaşan mitosların "gerçek" olmadığı, eril bir şekilde kurgulanmış metinler olduğu söylenebilir. Tarıma dayalı toplumların kadına verdiği değer hakkındaki bilgilerimiz arkeologların buluntuları yorumlamasına dayalıdır. Örneğin; doğanın yenilenmesi kadının doğurganlığı ile denk görülmüş ve tarımsal üretimin yani bereketin ilişkili olduğu kişiler kadınlar olmuştur. Bu da kadına tanrısal bir anlam atfetmiştir. Feminenlikle doğrudan ilişkili olan tanrıçalar Pantheon'da kendilerine yüksek bir yer bulamamıştır. Orta Çă̆ ise kadınlar üzerine uygulanan fiziksel ve psikolojik şiddetin kutsallaştırılarak meşrulaştırıldığı bir dönem olarak karşımıza çıkar. Kimliksizleştirilen kadın evin içinde konumlandırılır ve ev işlerinden sorumlu tutulur. Viktorya Döneminde "ideal kadın" kendisini eve hapseden, iyi bir eş ve anne figürüdür. Orta Çağ'daki "günahların sorumlusu olma" suçundan arındırılmış olan kadınlar bu dönemde "evdeki melek" olarak tasvir edilmişlerdir. Bu evdeki meleği Virginia Woolf (1966: 285) "yapısı, kendi düşünceleri ve istekleri olmasına engeldi, daha çok başkalarının düşüncelerine ve isteklerine boyun eğerdi" şeklinde tanımlamıştır. Sanayi Devrimi ile birlikte "erkek gücüne" dayalı üretim sistemine kadınlar da dâhil olmaya başlasa da hem düşük ücretler hem de kendilerine yüklenen "kutsal annelik" sıfatıyla baş etmek zorunda bırakılmışlardır.

Aynı şekilde sinemada gördüğümüz edilgen kadın temsiller de eril hegemonyanın pekiştirilmesine katkıda bulunur. Kadının bu edilgen konumunun değişim geçirmesi ise maalesef ki söylemi yeniden üretmektedir. "Erkek egemen toplumlarda, üretim araçlarının ve medya sahipliklerinin tamamını elinde tutan güçler ötekisini yani kadını yeniden inşa etme ve özgürlüğünü ona geri verme vaadiyle ona yeni roller sunar ve bu roller aracılığıyla tahakkümünü daha da güçlendirir" (Aşc1, 2019: 91). Çünkü “erkeğin dünyasını" anlatan erkek, kadını güçlü gösterirken aynı zamanda ona kendisine ait olan özellikleri yüklemiştir. Jung, kadınların içinde bulunan erkek arketipine animus der. "Bu arketip stereotipik olarak cesaret, liderlik, entelektüel akıl ve fiziksel güç gibi erkeksi özellikleri temsil eder" (Indick, 2011: 146). Bu nedenle "güçlü kadın" temsilleri aslında bir noktada "erkek temsilleri" nin bir tezahürü haline gelir.

\section{Monomit Kuramının Evreleri}

Kadın kahramanın yolculuk şeması lineer bir şekilde ilerlemez. Murdock'a göre (1990: 4) “kadın kahramanın yolculuğu, sürekli bir gelişim, büyüme ve öğrenme 
döngüsüdür". Erkek kahramanın yolculuğu başarıya ulaştıktan sonra son bulurken kadın kahraman yolculuğuna hayatı boyunca devam eder. Bu noktada aslında kadın kahramanın karşısına çıkan engellerin sürekli olarak onu yeniden eril sistem içerisine dâhil etmeye çalışan kısıtlayıcı kodlar ve kişiler olması dikkat çekicidir. Yolun sonunda içindeki eril ve dişil sesleri dengeye koyup başarıya ulaştığını düşünen kadın kahraman çıktığı diğer yolculukta yine aynı engellerle ve kısıtlayıcı unsurlarla karşılaşır. Yolculuğun ilk evresi olan "Geleneksel Kadın Kodlarından Kopuş" evresinde sistemin eril kodları karşısında kadın kahramandan ilk olarak feminen özelliklerini bırakması yani, geleneksel kadın kodlarından kopması beklenir. Bu nedenle "yolculuğun bu başlangıç aşaması genellikle pasif, manipülatif veya üretken olmayan olarak tanımlanan dişiliğin reddi ile başlar" (Murdock, 1990:6). Bu noktada kadına atfedilen bu özelliklerin aslında tüm insanlığa atfedilebilecek özellikler olduğu unutulmamalıdır. Fakat bu geleneksel "kadınsı" özelliklerin zayıf, değersiz ya da bağımlı olarak görülmesi doğalmış gibi gösterilmekte ve bu durum kadınlar tarafından da içselleştirilmektedir.

"Sinema, kadınlar ve dişillik ile erkekler ve erillik, kısacası cinsel farklılıklar üzerine mitlerin üretildiği, yeniden üretildiği ve bunların temsil edildiği kültürel bir pratiktir" (Smelik, 2008: 1). Bu pratik, bireylerin toplum normları çerçevesinde nasıl "normal" olacaklarını göstermesinin yanı sıra bu durumu içselleştirmelerini de kolaylaştırmaktadır. Buna göre sinema temsilleri "makbul olan" kadınlık ve "makbul olan" erkeklik rollerini göstermekte, başarıya ulaşmanın birincil koşulunun erkeklik ya da maskülen duruştan geçtiği mitini yeniden üretmektedir. Bu noktada yolculuğa başlayan kadın çevresini saran eril kodlardan arınmaya daha başlamamış, maskülen olarak atfedilen özelliklerin aslında kendi içinde insana ait özellikler olarak bulunduğunu farkına varmamıştır. Çünkü "kadın kendisini temsil edebilecek mitsel bir figürden yoksundur. Anne rol modelini zayıf kadından alır. Kız çocuk da anneden" (Cavarero, 1995: 3). Anne figürü kız çocuk için bir nevi rol modeldir. Aynı zamanda Adrienne Rich, Of Woman Born: Motherhood as Experience and Instution kitabında "anne, kendimizdeki kurbanı, özgür olmayan kadını, şehitleri ifade eder" (aktaran Murdock, 1990: 13) diyerek anne figürünün bireyde ifade ettiği edilgen konumu da tanımlamaktadır. Buna karşı geliştirilen "güçlü kadın” motifi ise maskülen duruşu ile patriyarkayı yeniden üreten bir konumda görülebilir.

Filmlerin kadın temsilleri konusundaki ana sorunu toplum içerisindeki "gerçek" ve birbirinden farklı olan kadınları değil, ideolojik olarak yapılandırılmak istenen tek tip kadını göstermeleridir. Klişeler ile şekillenen kadının sinema perdesi aracılığıyla filmdeki karakter ile özdeşleşmesi eril söylemi içselleştirmesini kolaylaştırır. Böylece zayıf, bağımlı, duyarlı ve duygusal olma özelliklerini kendisine atfeder ve "zayıflık, bağımlılık, duyarlılık ve duygusallığa dair kadınsı stereotipler olumsuz ve küçük düşürücü özellikler olarak algılanır" (Indick, 2011: 198). Bu "doğallaştırılmış" kadınsı stereotipler her ne kadar modern mitoslarda kırılarak "güçlü kadın" kahramanı üretse de kadın kahramanın zayıf olarak görülen kalıplardan sıyrılarak yolculuklarına başlamaları onların maskülenleştiklerini yani söylemi yeniden ürettiklerini de göstermektedir.

Yolculuğun birinci evresinde geleneksel kadın kodlarından kopan kadın kahraman, ikinci evresi olan "Geleneksel Erkek Kodlarıyla Özdeşleşme" evresinde klasik anlatıda erkek tarafından işgal edilmiş alan olan dış dünyaya adım atar ve kendisine bir yol gösterici bulur. $\mathrm{Bu}$ yol gösterici aslında geleneksel erkek kodlarını içselleştirmesi olarak görülebilir. Indick'e 
göre (2011: 199) "bu yol gösterici erkek olmalı, geleneksel Yaşlı Akıll Adam arketipinin işlevini yerine getirmelidir". Bu kişi "erkeğin dünyası" na adım atan kadın kahramanın akıl hocası olarak görülür ve bu noktada kadın kahraman dünyayı akıl hocasının yani bir erkeğin gözünden görmeye, anlamlandırmaya başlar.

"Denenmeler Yolu" olarak adlandırılan üçüncü evrede kadın kahraman bir takım sınavların üstesinden gelmelidir. Arketipik/geleneksel erkeksi özellikleri içselleştirerek "geleneksel kadınsı zayıflıklarını" tamamen baskılar. Kendini aramaya başlayan kadın kahraman kendi güvenli alanından bu evre ile beraber tamamen çıkar. Bu yeni alanda kadın kahramanın yerine getirmesi gereken üç görevi vardır. Bu görevler, aslında toplumda ona yöneltilen yanlış mitlerdir ve kendi sesini bulabilmesi için bu mitleri çürütmesi gerekir. Bu mitler: Bă̆ımlılık Miti, Kadının Değerce Aşağıda Olduğu Miti ve Romantik Aşk Mitidir (Indick, 2011: 199). Metaforik iki başlı ejderi öldüren kadın bağımlılık mitini çürütmüşs sayılır. Ejderha kadının etrafını saran eril söylemin kendisidir. Bağımlılık miti bir kadının otorite figürü (yani ejderha) olmadan var olamayacağıdır. Onun isteklerini yaptığı sürece özgürmüş gibi hisseden kadın özgür olabilmek için üretilen bu kodun yanlışlığını kanıtlamalı, tek başına ayakta kalabileceğini görmeli ve göstermelidir.

"Acımasız erkek dev", "kötü kadın cadı" ya da her ikisini de öldürdüğü ikinci sınavda kadın, değerce aşağıda olmadığını kanıtlayarak patriyarkanın söylemi karşısında eril dayatmalara karşı çıkarak iç sesini bulmalıdır. "Değerce aşağıda olma mitini yok etmek için kadın, kendi hakikat kılıcını taşımalı, bıçağını taş üzerinden keskinleştirmelidir" (Murdock, 1990: 56).

Son mit olan romantik aşk miti, kadının zorlukları aşıp kendini değerli olarak görmesinden sonra bir erkeğin varlığına ya da adına ihtiyaç duymadığını kanıtlaması için bir şanstır. Çünkü "kadınlık" erkekliğin karşısında, ona tezat olarak var olan bir kategori değildir ve kadının var olabilmesi için erkeğe ihtiyacı yoktur. Fakat kadın eril söylem tarafından çoğunlukla güçsüz ve bağımlı olarak gösterilir. Söylem "bağımlı ve bağımsız kadın temsillerini içerirken bağımlı olana olumlu, bağımsız olana ise olumsuz vurgu yapılmaktadır" (Atay, 2019: 266). Bu durumu çürütmek için ise kadın karşısındaki bu yanılsamayı aşmalıdır. Çünkü kadının serbestliği ve özgürlüğü erkeğin elinde değildir. Bu noktada korumacı ve kurtarıcı erkek karaktere karşı çı(a)mayan kadın kahraman yolun başına döner ve ilk başta reddettiği geleneksel kadın stereotipine yeniden bürünür. "Modern bir kadın kahraman olmaya son verir ve kendisini kurtarması için üzerinde güllerin olduğu yatakta cesur erkek kahramanı edilgince bekleyen geleneksel zor durumdaki genç kız halini alır" (Indick, 2011: 200-201). Bu miti çürüten kadın kahraman ise toplum tarafından ona dayatılan hegemonik erkekliğin üstesinden gelir ve kendi ayakları üzerinde patriyarkaya karşı durabilir.

Dördüncü evre, "Yanılsatıcı Başarı Hediyesi" dir ve bu evrede yanlış mitleri çürüten kadın kahraman kazandığı başarılar sayesinde Murdock'ın “The Superwoman Mystique" olarak tanımladığı bir yanılsama yaşar. "Kadın kahraman kendisinde 'kahramanca olana dair yanlış anlayışları' barındırır ve aynı anda hem erkek dünyasının bir şampiyonu hem de kadın dünyasının kraliçesi olabileceğine inanır" (Indick, 2011: 201). Buradaki "erkek dünyasının şampiyonu" olmak erkeğe atfedilen "dış dünya"da başarılı olmak, "kadın dünyasının kraliçesi" olmak ise dış dünyada ayakta kalarak kadınlar arasında da gücünü kanıtlamasını tanımlamaktadır. Bu durum da aslında eril söylemin kadın kahraman 
tarafından yeniden inşa edildiğini göstermektedir. Kadın kahraman her ne kadar karşısındaki eril tahakküme karşı koysa da bunu yaparken eril söylemi yeniden üretmeye devam eder. Hem "dış dünya"da kendisini kanitlarken geleneksel erkeklik kodlarıyla bütünleşir hem de kendisine dair her şeyi başaracağına yönelik yanlış bir izlenime kapılır. "Modern kadın erkeklere özgü değerleri kabul eder; erkeklerle ayn koşullarda düşündüğü, eylem gerçekleştirdiği, çalıştığı yarattığı için kendisiyle gurur duyar" (Walters, 2009: 138 akt. Aşc1, 2019: 91). İçselleştirilmiş erkeklik sonucunda da dördüncü evrede yanılsama yaşar ve bu durum da yine kadın kahramanın kendisini çevresindekilerden üstün görmesine ve bu üstünlükle birlikte kendi eril hegemonyasını kurmasına neden olur. "Geleneksel rollerinden kopmadan genç, güzel, eşi ve çocuklarıyla mutlu olarak sunulan özverili kadın imgesi aynı zamanda kamusal alanda kendini gösteren, iş hayatında başarılı olarak da sunulmaktadır" (Aşçı, 2019: 92). Fakat toplum tarafından ev dişında başarılı olan kadının bu sefer de anneliğ $i$ sorgulanır. Kendisine karşı yöneltilen bu tepkiler karşısında kadının tavrı çoğu zaman pasiftir. Murdock'a göre (1990: 63) 1980'lerin süperkadın kültü ile kadınlara her şeyi yapabilecekleri vadedilmiş; iyi bir kariyer, eşitlik ve sevgi dolu bir evlilik, neşeli bir annelik sözü verilmiştir. $\mathrm{O}$ zamana dek kendisine rol model olarak aldığı annesinden öğrendiği edilgenliği kıran/kırdığını düşünen kadın kahraman aslında kendi içinde de çok fedakârlık gösterir ve bu fedakârlıklar sonucu büyük bir tükenmişliğe sürüklenerek kontrolden çıkar. Dünyayı yol gösterici erkek figürünün gözünden gören kadın kahramanın tükenmişliğinin kaynağı aslında Büyük Sahtekârdır. Kendisine karşı da dürüstlüğünü kaybeden kahramanın "büyük sahtekâr rolünden feragat etmeden önce kendisini bu yıkıcı baba imajından kurtarması gerekir" (Murdock, 1990: 67). Fakat bu durum, geleneksel erkek kodlariyla bütünleşmiş olan ve dünyayı eril bir gözle gören kadın kahraman için oldukça zordur. Bu durum da beraberinde kadın kahramanın yolculuğundaki "asla yeterli olmama miti"ni getirir. Tüm inisiyatifi bilinçdışındaki erile veren kadın kahraman yetersiz olduğunu düşünür. Ruhsal uyanışına giden anahtar ise bu mitin yanlış olduğunu kavraması, içinde var olan cesaretin yeterliliğini fark etmesi ile gerçekleşir.

Dördüncü evrede yaşanan bu acı sonrasında kadın kahraman beşinci evrede erkeğe "hayır" diyerek gücünü kanıtlama çabasına girer. Burada karşı çıkılan erkek kral temsilidir ve içsel ya da dişsal bir faktör olabilir. Yolculuğun başında özdeşleştiği akıllı yaşlı erkek arketiplerinden birisi olan kral bu sefer karşı çıkılması gereken bir figürdür. "Jungcu ikiliğe uygun olarak gölge baba figürü de çoğu kez yanlı̧̧ yol gösterici ya da olumsuz baba figürüyle temsil edilir" (Indick, 2011: 144). Kadın kahraman karşısındaki eril gücün kurbanı olmak zorunda kalmak yerine hayatını kendi eline almayı tercih eder. Murdock'a göre burada "hayır" demek aynı zamanda kralın ölmesi anlamına da gelir. Bunun sonunda kadın kahraman altıncı evrede reddettiği kadınsı özellikler ile tekrar karşılaşır, anne arketipi ile yeniden ilişki kurar. Fakat bu seferki anne Ana Tanrıça arketipi olarak karşımıza çıkar. Bu arketip, yaratıcı ve yok edici gibi iki farklı özeliği içinde barındırır. "Bu olay mitolojik bağlamda iki zıt gücün savaşı olarak değil, daha çok iki karşıt kutbun zararsız ilişkisi olarak görülür" (Dunn Mascetti, 2000: 36). Jung'un ikilikleri açısından bakıldığında bu iki tanrıça aslında birbirinin tamamlayıcısıdır.

Altıncı evre olan "Tanrıça'yla Karşılaşma" evresi içerisinde ruhsal uyanışı, yani inisiyasyonu barındırır. Buradaki tanrıça arketipi dişil gücü imler. Yolculuğun başında reddedilen anne ve geleneksel kadınlık ikiliğin kötü figürüyken tanrıça iyi tarafıdır ve aslında kadın kahramanın yol boyunca kaybettiği parçalarını arama mücadelesini gösterir. 
$\mathrm{Bu}$ arketip sayesinde anne/kız çocuk bölünmesi giderilmeye başlanır ve kadın kahraman içindeki anima ile animus ${ }^{1} \mathrm{u}$ dengeleyerek bir değişim geçirir. Bu sayede büyük sahtekârın verdiği acıdan kurtulmaya başlar. Bazı durumlarda ise yaşadığı bu düşüş ile kadın kahraman depresyon dönemine girebilir. Bu dönemin aşılması için ise başarılı bir inisiyasyon ${ }^{2}$ sürecinin geçirilmesi gerekir. "İnisiyasyon bir varlık durumundan bir başka varlık durumuna geçiştir" (Tecimer, 2006: 49). Bunun sonucunda bireyin statüsünde bir değişim olduğu görülür. Kadının inisiyasyon süreçleri genellikle ilk menstrüasyon döneminden sonra görülür. Tecimer'e göre (2006: 57), kadınların yaşadığı bu inisyasyonda toplumdan bir tecrit söz konusudur. Freud'un (1998: 43) da geçici tabular olarak tanımladığ1 menstrüasyon, hamilelik, doğum ve menopoz gibi deneyimlerin inisiyasyon süreçlerinde uygulanan tecridin altında yatan sebep ise kanaatimce korkudur. Korkulan kişiyi toplumdan uzaklaştırma ve ortada korkacak bir durum kalmadığında geri topluma kabul etme durumu inisiyasyon rituslarının işleyişini açılamaktadır. Bu tecritlerden geçici olan soyutlanma çeşidi ise kadın inisiyasyonunda görülen durum ile benzerlik gösterir.

"İçindeki Kadınla Acilen Yeniden Bağlantı Kurma Arzusu" yolculuğun yedinci aşaması olarak karşımıza çıkar. Yolculuğun bu evresi kadın kahramanın bilinçdışına, ruhuna ve ruhani ihtiyaçlarına yöneliktir. Modern toplumlarda kadınların "geleneksel kadın" özellikleri taşıması aynı zamanda da "erkekler gibi" üretim ilişkilerine dâhil olması beklenir. Her ikisini de başarmak zorunda hisseden kadın bu durum karşısında maskülen özellikleri ile ayakta kalmaya çalışarak anima ve animus arasındaki dengeyi bozar. Beden ve ruh arasındaki bu bölünmeyi gidermek bu evrenin ana problemidir. Hemen sonrasında gelen "Anne/K1z Çocuk Bölünmesini Gidermek" evresi aslında kadın kahramanın kendisiyle barıştığını gösterir. Örümcek Büyükanne ${ }^{3}$ arketipi bu evrenin bütünleşmeyi kolaylaştırıcı figürüdür. Bu arketip kadın kahramanın Ana Tanrıça ile son yeniden bağlantısıdır.

Dokuzuncu evre "İçindeki İyi Kalpli Erkeği Bulmak" yani tüm karşıtlıkları birleştirmektir. Bu evrede görülen Hieros Gamos ${ }^{4}$ yoluyla kadın kahraman tüm karşıtlıkları birleştirir, hem feminen hem de maskülen özelliklerini kabullenir. Murdock'ın (1990: 160) bahsettiği üzere "kutsal evlilik ego ve özün evliliğidir". Kadın kahraman yol boyu edindiği deneyimlerden kazandığı bilgelik ile bir değişim geçirir. Bu deneyim ve değişim sonucu kadın kahraman ateşi insanlık ile paylaşan Prometheus gibi kazandığı bilgeliği dünya ile paylaşmak adına yolculuğunu tamamlar. Böylece "dünyadaki kadın, erkek ve çocuklar onun yolculuğuyla dönüşüm geçirir" (Murdock, 1990: 168).

Son evre olan "İkiliğin Ötesi", özünde yolculuğunun sonunda ruhani çift cinsiyetli olan kahramanı tanımlar. "Ta eski çağlardan beri mitoslarda aynı beden içinde, erkek ve kadını birlikte yaşadığ1 fikri görülmektedir" (Jung, 2006: 258). Jung'a göre ruhani çift cinsiyetli olmayı temsil eden mitolojik arketip ise Hermafrodit ${ }^{\prime}$ tir. "Aristophanes, insanların

\footnotetext{
${ }^{1}$ Jung'a göre anima erkeğin bilinçdışının feminen yanı, animus ise kadının bilinçdışının maskülen yanıdır.

2 “Birtakım gizemlerin öğretildiği, gizli bilgilerin aktarıldığı rituslar bütünü” (Tecimer, 2006: 48). İnisiyasyon evresinin amacı bireye yeni bir yaşama doğmak için öldüğünü hatırlatmaktır. Bu nedenle filmlerde inisiyasyon yeniden doğuş ile gösterilir.

3 “Kızılderili mitolojisinde sık sık karşımıza kurnaz, anaç, iyi huylu bir büyükanne karakteri, Örümcek kadın çıkmaktadır" (Tanpolat, 2016: 108). Örümcek kadının Dünya'ya güneşi getirdiği düşünülür.

4 Tanrı ve tanrıça arasında gerçekleşen kutsal evlilik/birleşme törenine verilen isim.

5 "Hem erkek hem de dişi gametleri bulunan (birey), erselik, hünsa" (Türk Dil Kurumu, 2019). Yunan mitolojisinde Aphrodite ve Hermes'in çocuğu, hem erkek hem de dişi özelliklerine sahip olan tanrı.
} 
en ilkel çağlarda hem erkek, hem de dişi olduklarını, sonra bu yüzden fazla güç kazandıkları için tanrılarca ikiye bölündüklerini anlatır" (Erhat, 2011: 140). Kendi içindeki eril ve dişil arasında denge kuran kadın kahraman Aristophanes'in de dediği gibi büyük bir güç kazanmış olur ve yolculuğunun sonuna gelir.

\section{Bulgular}

Alice in Wonderland, El Laberinto del Fauno ve Valerie A Týden Divu örneklerindeki ortak nokta kadın kahramanın tek başına yola çıkıyor oluşudur. Üç kadın kahraman da fantastik bir yolculuğa çıkar ve bu yolculuklar üçünün de içinde bulundukları baskıcı toplumlara karşı bir savunma mekanizması olma özelliği taşır. Bu açıdan üç karakter de fantastik yolculuklarında başarılı olduklarında kendilerini tamamlanmış hissedecek, kendi gerçekliklerinde ki eril tahakküme karşı gelerek kahraman olabilecektir.

Üç karakterin de hayali evrenleri birbirlerinden farklıdır. Alice ve Ofelia'nın hayali evrenleri içinde yaşadıkları gerçekliklerinden bağımsız, farklı bir coğrafyada ya da görünümdedir. Valerie'nin hayali evreni ise kendi yaşadığı çevrede, gerçekliğinin içine yedirilmiştir. Üç karakterin de hayali evreni bir oyun gibi kurgulanmış ve gerçeklikten bir kaçış olması için oluşturulmuştur. Kadın kahramanın döngüsel yolculuğunu tasvir eden bu evrenlerden her biri farklı bir savunma mekanizması olarak karşımıza çıkar. Alice'in hayali evreni; orada bir süre vakit geçirmesi, kaçtığı gerçeklikteki kişiler ile bu evrende karşılaşmaması gibi durumlardan ötürü rüya ${ }^{6}$ kategorisine dâhil edilebilir. Ofelia ise günün farklı zamanlarında ve farklı mekânlarda, yalnız kaldığında Fauno (Doug Jones) ile iletişim kurar. Bu açıdan onun hayali evreni bir gündüz düşüne ${ }^{7}$ benzemektedir. Valerie ise günlük yaşam pratiklerine hayali evrenini entegre ederek diğer iki örnekten farklı bir savunma mekanizması geliştirmiştir. Meydanda geçen eğlence sahnesi, kilise sahnesi ya da sokakta tek başına yürüdüğü sahne gibi sahnelerde anlık ya da sürekli olarak Sansar'1 (Jirí Prýmek) görmesi, onun yaşadığı deneyimin halüsinasyon ${ }^{8}$ olabileceğine dair ipuçları verir.

Rüya, gündüz düşü ve halüsinasyon arzularımızın bir yansımasıdır. Bu açıdan bakıldığında rüyalarımızda, gündüz düşlerimizde ya da halüsinasyonlarımızda peşine düştüğümüz şey arzu nesnemiz, yani objet petit $a^{9^{\prime}}$ dır. Savunma mekanizması olarak kabul ettiğimiz hayali evrenlerde kahramanın karşısına çıkan zorluklar da arzunun nesne nedenine ulaşmamak için kendi önüne koyduğu bilinçdışındaki engellerdir. Alice'in Jabberwocky'yi (Christopher Lee) öldürmeden önce karşısına çıkan engeller ve Jabberwocky'yi öldürdükten sonra diğer gerçeklikte kendisine başka bir hedef koyması da arzunun ulaşılamaz oluşundan kaynaklıdır. Aynı şekilde Fauno'nun Ofelia'nın karşısına koyduğu engellerin sebebi de budur. Valerie a Týden Divu'da ise Valeriénin ilk kez regl olduğunu gördüğümüz sahne aynı zamanda üzerindeki toplum baskısının da yön değiştireceğini göstermektedir. Çünkü Valerie ilk menstrüasyonu ile birlikte toplum için "kadın" olmuştur. Valerie'nin

\footnotetext{
${ }^{6}$ Freud (2014: 13) uykuyu "uyuyan kişinin dış dünyada neler olup bittiğini bilmek istemediği, bütün ilgisini bu dünyadan kopardığı bir durum" olarak tanımlar. Bunun sebebi de rahim içine geri dönme isteğidir. Rank'e göre (2001: 76) uyku durumunda görülen rüyalar doğum travmasının aşılamamış olmasıyla ilgilidir.

7 Uyanık durumda görülen rüyalardır. Bu fenomeni rüyadan ayıran ikinci durum ise bireyin gündüz düşünün bir fantezi olduğunu farkında olmasıdır.

8 Bireyin duyuları, orada olmamasına rağmen gördüğü nesneler nedeniyle hareket halindedir. Halüsinasyon birey için oldukça canlı ve dış dünyada görünürdür.

${ }^{9}$ Lacan imkânsız arzu nesnesini objet petit a olarak tanımlar. Yani objet petit a "gerçek" bir nesne değil, bir fantezi nesnesidir.
} 
halüsinasyonlarında Sansar adındaki vampiri görmesi ise yaşadığı bu değişim ile birlikte toplum ve toplumsal kurallar tarafından sömürülmekten korktuğunu göstermektedir. Koruyucu özelliği olduğunu düşündüğü inci küpelerini kaybetmesi ve ardından da regl olması Valerie' nin büyümeye karşı duyduğu korku ve çekincelerini gösterir.

Bilinçdışının dışavurumu olan bu üç mekanizma arzuların bir yansıması olduğu için hayali evrendeki bu yolculuklar aslında obje petit a'nın peşinde koşan kadın kahramanları anlatmaktadır. Objet petit $a^{\prime}$ nın ulaşılamazlığı, kadın kahramanın yolculuğunun sonsuzluğunu da açıklar. Yolculuğu boyunca aslında dürtü tatmini için uğraşan kadın kahraman yolculuğunun sonunda jouissance ${ }^{10^{\prime}} 1 \mathrm{n}$ imkânsızlığ 1 nedeniyle farklı bir yola girer ve hayatı boyunca jouissance'ı tatmin etmek için çabalar. Sadece travmaların çözümü için değil, aynı zamanda bilinçdışı düzeyde arzu nesnesini aramak ve dürtü tatminini sağlamaya çalışmak için kurulan savunma mekanizmaları kadın kahramanın yolculuğunun hem sebebi hem de engelidir.

Kahramana tatmin hissini veren jouissance'ın imkânsızlığıdır. Film boyunca sürekli bir şeyleri başarmaya çalışarak sona ulaşmaya çalışan kahraman, filmin sonunda yine tatmin hissini tam olarak yaşayamaz. Kadın kahramanın döngüsel olan yolculuğunun sonu, bir başka yolculuğunun başlangıcıdır ve her yolculuğunda aslında tatmin edilmesi imkânsız olan jouissance' 1 tatmin etmeye çalışır.

Üç örnekteki savunma mekanizmalarının hepsi aslında kadın kahramanların üstesinden gelmek zorunda kaldıkları durumların üzerini örter. Bu zorlu durum ise karşılarındaki tahakküm kurucu yapı olan patriyarkadır. Kadın kahramanların çıktıkları hayali evrenlerdeki bu fantastik yolculuklar onların toplumsal kalıpları reddederek kendilerini gösterme çabalarını yansıtır.

Kadın kahramanın yolculuğunu önemli kılan nokta toplumsal cinsiyet rolleri tarafından şekillenmesidir. Kadın bir süre buna karşı çıktığını varsayarak ilerlemesine rağmen aslında eril söylemi yeniden üretmektedir. Feminen özellikleri ile yeniden bağlantı kurduğu evreye kadar aslında içindeki eril tarafından yönlendirilerek farkında olmadan cesur, koruyucu, güçlü olma gibi özellikleri erkeğe; duygusal, çaresiz ve korunmaya muhtaç olma özelliklerini ise kadına atfeder. Tüm bunları aynı anda içerisinde barındırabildiğini anladığında ise aslında bu tip ikili cinsiyet sistemine dayalı toplumsal kodların biyolojik cinsiyetlere bağlı olmaksızın herkesi kapsayıcı olduğunu fark eder.

Alice ve Ofelia kendi biyolojik annelerini kötü anne arketipi olarak kodlarken Valerie büyükannesini (Helena Anýzová) bu arketipe dâhil eder. Bunun sonucunda üçü de anne arketipinden edindikleri edilgen kadın bilgilerinin kötülüğünü farkına vararak onlara karşı gelir, geleneksel kadın kodlarından uzaklaşır ve içlerindeki maskülen yön ile bütünleşirler. Buradaki anne figürleri şeytani özellikler sergilemese de kadın kahramanların üzerlerinde kurdukları tahakküm nedeniyle bu arketipe dâhil edilirler. Üç örnekte de bulundukları kültürel ve sosyal çevreden kaçmak ister ve üç kahramanın da yola çıkış itkisi bu kaçma isteğidir.

\footnotetext{
${ }^{10}$ Freudyen paradigmada haz, gerilimin boşalması ve tatmin ile ilgilidir. Fakat Lacan' in jouissance olarak tanımladığı kavram Freud'un haz ilkesinin ötesinde konumlanır. Jouissance hazzın tatmini değil, dürtünün tatminidir. Haz benliğin iç dengesini korurken jouissance ulaşılamaz oluşuyla bu dengeyi bozmaktadır.
} 
“Geleneksel Erkek Kodlarıyla Özdeşleşme” evresinde Alice Çılgın Şapkacı (Johnny Depp) ile, Ofelia Fauno ile ve Valerie Orlík (Petr Kopriva) ile karşılaşır; onlarla özdeşleşir. Bu noktada kadın kahraman aslında her ne kadar güçlenmeye başladığını düşünse de erkeğin "kurtarıcılığına" muhtaç olarak temsil edilmektedir. Kadın kahramanın kendinde eksik olarak gördüğü şeyleri tamamlayan bu karakterler Alice için özgürlüğü, Ofelia için gücü, Valerie için ise sevgiyi tanımlar. Alice ve Şapkacı arasındaki ilişki eğlenceliyken Fauno, Ofelia için sahip olmadığı otoriter baba figürüdür. Valerie ve Orlík ise ensest ilişkiyi göstermektedir ve diğer örneklere benzer bir şekilde Orlík koruyucu karakterdir. Hem yol gösterici hem de koruyucu olan bu karakterler gözünden dünyayı görmeye başlayan kadın kahramanlar geleneksel kadınsı özelliklerinden sıyrılarak erkeğe atfedilen; cesaret, gözü pek olma ve zorluklarla başa çıkabilme gibi özelliklerini ortaya çıkarırlar.

Kadın kahramanların çıktıkları fantastik yolculuklar bilinçdışı tarafından yapılandırılır. Bir çeşit savunma mekanizması olarak görülebilecek olan bu yolculuklar ve engellerle başa çıkma yolları üç karakter için farklı olsa da engellerin oluşum nedenleri ile kahramanların bu engelleri aşarak söylemek istedikleri aynıdır.

Üç kahramanın da karşısında yenmesi gereken, kendi gerçekliğinin bir yansıması bulunur. Bu yansımalar aynı zamanda kahramanın üzerinde otorite kurmaya çalışan figürlerdir. Alice' in karşısında Hamish (Leo Bill), Hamish' in ailesi ve kendi ailesi dolayısıyla; Viktorya Dönemi İngiltere'si bulunur. Ofelia ise Franco'nun bir yansıması olan Vidal'e (Sergi López) karşı durur. Valerie'nin durumu ise farklıdır. Onun yolculuğu ilk menstrüasyonu ile birlikte çocukluktan ergenliğe geçiş anlamı da taşır. Karşısında durduğu şey ise Çekoslovak toplumunun baskıcı yapısının vücut bulmuş hali olan Sansar karakteridir.

Çözülmesiyle birlikte kahramana kurtarıcı olma özelliğini getiren bağımlılık mitini Alice Şapkacı'yı Salazen Grum'dan kurtardığında aşar. Ofelia Fauno'nun verdiği görevlerden ilki olan incir ağacını dev kurbağadan kurtarma görevini başarılı bir şekilde yerine getirerek, Valerie ise Orlík'i Sansar'ın elinden kurtararak aşmaktadır. Bu üç görev de aslında gerçek düşmanı öldürmeye giden yolda kadın kahramanın geçmesi gereken engelleri anlatmaktadır. Buradaki asıl düşman Alice in Wonderland'de ejderha Jabberwocky ve Kızıl Kraliçe (Helena Bonham Carter), El Laberinto del Fauno' da Vidal, Valerie A Týden Divu'da ise Sansar'dır. Bu üç düşmanın ortak özelliği ise aslında kadın kahramanın kaçtığı eril söylem tarafından inşa edilmiş olan toplumun yansımasıdır.

Kadının değerce aşă̆ıda olduğu miti çürütüldüğünde kadın kahraman güçlü olduğunu kanıtlamış olur. Bunun için Alice, bir phallus imgesi olan Vorpal kılıcını ele geçirerek gücünü kanıtlar ve Bandersnatch'in saldırgan yapısını tersine çevirerek metaforik olarak acımasız erkek devi öldürür. Ofelia'ya Fauno tarafında verilen ikinci görev onun ikinci miti çürütmesini sağlar. Alice ile benzer bir şekilde phallus imgesi olan altın saplı hançeri ele geçirerek Pale Man (Doug Jones) görevini tamamlar. Perilerin onun için kendilerini feda etmeleri de Ofelia'nın aslında değerce aşağıda olmadığını anlamasını sağlar. Valerie ise Elsa (Helena Anýzová) tarafından kaçırıldığında aslında gençliğin sırrının kendisi olduğunu öğrenir. Elsa'nın sandığı gibi değerce aşağıda olmayan Valerie bu miti çürütmüş sayılır.

Son mit olan romantik aşk mitini Alice, Salazen Grum'da Stayne (Crispin Glover) tarafından sıkıştırıldığında onu reddederek çürütmüş olur ve bir erkeğin varlığı olmadan var olabileceğini kanıtlar. Ofelia'nın son görevi erkek kardeşini Fauno'ya kurban vermektir. 
Kahramanın Fauno'ya karşı çıkışı aslında parlak zırhlı şövalyeyi öldürdüğünü gösterir. Çünkü bu şekilde erkek karşısında pasif konumda olmadığını, onun isteklerine boyun eğmeden de var olabileceğini gösterir. Valerie'nin bu miti çürütmesi ise Orlík'in ağabeyi olduğunu öğrendikten sonra onu reddederek ondan uzaklaşması ile olur.

Başarılı bir şekilde mitleri çürüten Alice, Ofelia ve Valerie yolculuğun bir bölümünde kendilerini yetersiz görmeye başlarlar. Alice Vorpal kılıcını Beyaz Kraliçe'ye (Anne Hathaway) teslim ettikten sonra aslında ondan beklenenin farklı bir şey olduğunu öğrenir ve kendisini bu konuda yeterli görmez. Ofelia ise ikinci görevde başarısız olmuş olmaktan korkar. Fauno'nun ona kızmasından sonra kendisine yeraltı dünyasının kapılarının kapatıldığını ve yetersiz olduğunu düşünür. Valerie ise Sansar'ın babası olduğunu öğrendiğinde onu iyileştirici gücü olan öpücüğü ile kurtarabileceğini düşünür ve başaramadığında aynı şekilde kendisini yetersiz hisseder.

Beşinci evrede gördüğümüz karşı çıkış sadece erkek karakterlere değil eril güce karşı bir duruş olma özelliği taşır. Bu açıdan Alice'in savaşma konusunda Beyaz Kraliçe'ye karşı çıkması eril güç olarak iktidara karşı çıkması anlamına gelir. Ofelia'nın annesinin yatağının altına iyileşmesi için Fauno'dan aldığı adamotunu yerleştirdiğini fark eden Vidal'in adamotunu atmak istemesi üzerine Ofelia ona karşı çıkar. Valerie'nin karşı çıktığı eril güç de Sansar yani baba karakteridir. Kendisine saldıran babasına "hayır" diyerek ona karşı çıkan Valerie bir sonraki evreye geçmeyi hak eder.

Uyanışın gerçekleştiği altıncı evrede kadın kahramanlar değişim geçirerek yolun başındaki kadından farklı biri haline gelirler. Absolem (Alan Rickman) ile konuşması sırasında kendi iç sesini farkına varan Alice, zırhını giyerek Vorpal kılıcını eline alır ve ana tanrıça figürü olan Beyaz Kraliçe'nin yanında yer alarak "bir savaşçı olarak" yeniden doğar.

Ofelia için tanrıça figürü onu koruyan karakter olan Mercedes'tir (Maribel Verdú). Mercedes'in kaçtıktan sonra Ofelia için geri dönüşü kadın kahramanın Ana Tanrıça ile son karşılaşmasını temsil eder. Ofelia kardeşini de alarak labirente kaçtığında Vidal tarafından takip edilir ve labirentin içinde öldürülür. Bu gerçeklikte ölen Ofelia' nın yolculuğu sona erse de aslında farklı bir gerçeklikte farklı bir yolculuğa devam ettiği görülür. Bu evrede karşımıza çıkan yeniden doğuş, El Laberinto del Fauno'da bizzat ölüm ve doğum üzerinden gösterilmektedir. Ofelia'nın yeraltı ülkesinde yeniden doğuşu başarılı bir inisiyasyon yaşadığını gösterir.

Valerie Sansar'a karşı çıktıktan sonra uyandı̆̆ı bodrumdan kaçar ve Orlík'ten gelen veda mektubunu okurken vampir büyüsü altındaki arkadaşı Hedvika (Alena Stojáková) ile karşılaşır. Elsa'nın aksine Valerie'ye iyi davranması Hedvika'yı Ana Tanrıça arketipine uygun hale getirir. Ana Tanrıça arketipinin kahramana gösterdiği dişil güç, kahramanın anne/kız çocuk bölünmesini gidermesini sağlarken aynı zamanda yeniden doğuşa giden kapıyı aralar.

Ana Tanrıça ile karşılaşma sonrasında yolun başında zayıflık olarak kodladığı geleneksel kadın kodlarının yokluğunu hisseden kadın kahraman yedinci evrede içindeki eril ve dişil arasında denge kurması gerektiğini anlar. Yeniden doğuş sonrası daha da güçlenen kadın bu dengeyi kurduğunda gücünün sınırlarına ulaşır. 
Alice Absolem ile yaptığı konuşmasında aslında kim olduğunu ve ne yapması gerektiğini anlar. "Ben Alice Kingsleigh'yim" (Burton, 2010) cümlesi yolculuğun başında koptuğu "güçsüz" görülen özellikleri ile bir barışma anlamı taşır. İçindeki kadınla acilen yeniden bağlantı kurma arzusu kadın kahramanın kendi yolunu çizebilmesi için önemlidir. Mitlerde kadın sembolü değiştirici ve yaratıcıdır. Bu açıdan bakıldığında Alice'in kendisi bir değişim yaşarken aynı zamanda Wonderland'in Kızıl Kraliçe'nin elinde kötüye giden kaderini de değiştirmektedir ve yaşanan değişim filmde Absolem'in ördüğü koza üzerinden gösterilir.

Ofelia'nın özellikle annesinin ölümünden sonra kendisini kardeşinin koruyucusu olarak görür ve yeraltı dünyasına onu da beraberinde götürmek ister. Ofelia'nın kardeşini Vidal'den kurtarmak istemesi kurtarıcı kahraman olmak istemesi ile ilişkilidir ve arketipik olarak içindeki eril yönü temsil eder. Kardeşine duyduğu sevgi ve onun için kendi hayatından vazgeçme vefakârlığını göstermesi ise arketipik dişil yönünü göstermektedir. Bu açıdan Ofelia'nın içindeki eril ve dişil yön birleşmiştir.

Valerie a Týden Divu örneğinde içindeki kadınla bağlantı kurma Valerie'nin yakılma sahnesinde gösterilir. Cadı/büyücü imgesi, özellikle antik inanç sistemlerinde önemli yer tutar. Tanrısal gücün bahşedildiği bu karakterler tek tanrılı inanç sisteminin gelişmesi ile kötü karakterler haline gelmiş, bu nedenle de cezalandırılmışlardır. Özellikle Orta Çağ Avrupası'nda cadılık ile ilişkilendirilen kadınların yakılarak cezalandırılması, Orta Çağ Kilisesinin kadınlar üzerinden meşrulaştırdığı eril hegemonyası olarak görülebilir. Doğa, dolayısıyla da feminen güçler ile özdeşleştirilen cadılık, aslında Valerie'nin içindeki kadınla yeniden bağlantı kurma isteğini gösterir. Yakılma sahnesi ise yeniden doğmak için aşması gereken bir engeldir. Valerie'nin yakıldıktan sonra incisi sayesinde kurtulması ve bir kez daha yeniden doğuşu ise bu isteğinin gerçekleştiğini gösterir. Valerie, yaşadığı değişimi sürekli bir yeniden doğuş olarak görür. Bu nedenle Valerie a Týden Divu'da kadın kahraman kendisindeki değişimleri her farkına vardığında bir başka uyanış gerçekleştirir. Filmin sonundaysa Valerie, "umarım tüm büyüler kaybolmuştur" (Jireš, 1970) diyerek de son uyanışını gerçekleştirir. Çıplak bir şekilde yatağa uzanması kendisini anne karnındaki cenin gibi görmesi ve değişimlerini kabul ederek yeniden doğmak istemesi ile ilgilidir.

İçindeki kadınla yeniden kurulan bağlantı anne/kız çocuk bölünmesinin giderilmesini sağlar. Alice, Absolem ile konuşması sırasında Wonderland'e daha önce geldiğini hatırlayarak "gerçek Alice" olduğunu farkına varır ve bu noktada Wonderland ile yeniden bağ kurar. Wonderland filmdeki anne rahmini simgeleyen bir mekândır ve Alice'in filmin başında Wonderland'e düşüşü, anne rahminin konforlu alanına geri dönme isteği ile ilgilidir. Bu bağlamda filmde gördüğümüz anne ve kız çocuk bölünmesi aslında Alice'in Wonderland'in "gerçek" olduğunu fikrini kabul etmesi ile gerçekleşir. Bu evrede kadın kahramanın başarıya ulaşması için tanrıçanın kendisi olması gerekir. Zırhını kuşanarak Vorpal kılıcını taşıyan Alice gücün sahibi olan tanrıça konumuna erişir.

Ofelia ise labirentte kardeşini korumak adına yeraltı dünyasına inme teklifini reddeder. Bu durum da onu hem cesur hem de fedakâr bir kahraman yapar ki onun asıl gücü de budur. Benzer şekilde labirent, Ofelia'nın anne rahmine geri dönme isteğini yansıtır ve kardeşi adına bu konfordan vazgeçmeye hazır olduğunu göstererek "kadın ile özdeşleştirilen" fedakarlık özelliği üzerinden tanrıça olduğunu gösterir. 
Valerie' nin karşılaştığı örümcek büyükanne figürü vampir büyüsünden kurtulmuş olan kendi büyükannesidir. Valerie kaybettiği içindeki kadın ile bağını büyükannesi vasitasiyla yeniden kurar.

Kadın kahraman yolculuğun dokuzuncu evresinde kutsal evliliği hak eder. Bu evlilik ego ve özün evliliğidir. Alice in Wonderland' de gördüğümüz Hieros Gamos, id olan Şapkacı ile ego olan Alice'in birlikteliğidir. Şapkacı aslında Alice'in içindeki iyi kalpli erkeği gösterir. Onun varlığı ile dengelenen kadın kahraman yolculuğundan çıkardığı dersler ile hayatına (yani diğer yolculuklarına) yön verebilir. Tüm karşıtlıkların birleşimi olarak görülen Hieros Gamos, El Laberinto del Fauno'da Ofelia'nın yeraltı dünyasında ailesi ile birleştiği sahnede görüntülenir. Hedefine ulaşan kadın kahraman yerin üstünde ve altında olan birbirine zıt iki gerçekliğin birleşimi ile yolculuğunun sonuna yaklaşır. Valerie için ise iyi kalpli erkek Orlík'tir. Bu filmde görülen kutsal evlilik filmin sonundaki buluşma sahnesidir. Orlík buluşma isteğini Christopher Marlowe'un Dr. Faustus oyununun davetiyesinin üzerine yazdığı gizli bir mesaj ile kadın kahramana iletir. Valerie'nin Sansar'ın çekiciliğine kapıldığını ve bu nedenle kendisini terk ettiğini düşünen Orlík'in gözünde Valerie, ruhunu şeytana satan Faustus'un kendisidir. Faustus hikâyede hatasını anlayarak çevresindekilere yaptığı anlaşmadan pişman olduğunu söyler. Valerie'de benzer bir pişmanlık duymaktadır ve kutsal birleşme isteğindeki bu ironi aslında kadının içindeki erkeğin, kadına olan bir sitemi olarak görülebilir.

Kadın kahraman yolculuğunun son evresinde içindeki dişil ve eril özellikler arasında denge kurarak ikiliği gidermiş olur ve bu da gücünü sadece maskülen yönlerinden değil, aynı zamanda feminen yönlerinden de aldığını anlaması anlamına gelir. Bu yolculuk sonunda kadın kahramanın kazandığı en önemli şey psikolojik dengesidir. Bu denge kahraman olmanın sadece erkek karakterlere has bir özellik olmadığını, kahraman olmak için de sadece eril özelliklerin değil, dişil özelliklerin de var olması gerektiğini göstermektedir.

Jabberwocky ile karşılaşan Alice savaşırken kahvaltıdan önce inandığı altı imkânsız şeyi saymaya başlar -ki bunu yapmayı babasından öğrenmiştir-. Bu kahramanın iki gerçekliği de içselleştirdiğini gösterirken aynı zamanda kurduğu dengeye de işaret eder. Wonderland'de tamamladığı yolculuğu sonunda diğer gerçekliğe dönen kahramanın kendisine başka bir yol çizmesi ise kadın kahramanın yolculuğunun sonsuz ve döngüsel olduğunu gösterir.

Ofelia'nın labirentte öldükten sonra yeraltı dünyasına gidişi sonraki yolculuğunun başladığını gösterir. Bu yolculuğunda diğer gerçeklikte kaybettiği annesi, babası ve kardeşine kavuşarak iki gerçekliği birleştirir. Her iki yönü ile denge kurmayı başaran Ofelia' nın ödülü bir yolculuğu sonlandırarak yeni bir yolculuğa başlamaktır.

Valerie'nin büyükannesi filmin sonunda ona anne ve babası hakkındaki gerçekleri anlatır. Anne ve babasına kavuşan Valerie ise kendi içsel dengesini bulur. Yolculuğu boyunca karşılaştığı karakterlerin hepsini gölün etrafındaki ormanlık alanda gören Valerie aslında hepsi ile bütünleşerek yolculuğunu tamamlar. Bunun verdiği güç ve huzurla birlikte de ağaçların ortasında duran beyazlar içindeki yatağına uzanır ve film boyu süren yolculuğu bu şekilde sonlanır. 


\section{Sonuç}

Tim Burton'in Alice in Wonderland'i Lewis Carroll'ın Alice's Adventures in Wonderland'inin sadece uyarlaması değil, aynı zamanda kendi görme biçimiyle birlikte yeniden okumasıdır da. Kitabından farklı olarak Alice filmde 19 yaşındadır ve Burton bu durumu şu şekilde açıklar: "Çünkü o yaş bana tam bir dönüm noktası gibi geliyor. O yaşta toplum içine girmeye veya evlenmeye ya da başka şeylere yöneliyorsunuz" (Ekince, 2010). Bu nedenle filmdeki Alice kitaptaki Alice'in büyümüş halidir ve sadece Wonderland'e seyahat eden bir kadın kahraman değil, dönemin sosyo-ekonomik ve toplumsal olaylarını da yansitan bir kadın kahramandır. Wonderland ise aslında döneminin izlerini yazarın, sonrasında ise yönetmenin bakışından izleyicilere yansıtır.

El Laberinto del Fauno, The Devil's Backbone'da olduğu gibi Guillermo del Toro'nun İspanya'nın hiçbir zaman iyileşmediğini düşündüğü bir yarasına bakma şeklidir. Yetişkinler İç Savaş ile uğraşırken Ofelia' nın masallara tutunması arasındaki zıtlık aynı zamanda kadın kahramanın fantastik yolculuğunun da sebebidir. Del Toro iç savaşın İspanya' da bir hayalet gibi hala daha dolaştığını düşünmektedir. Bu tarihsel süreci masalsı bir anlatımla aktarmayı seçmiş yönetmen bu seçimin sebebini şu şekilde açıklar: "Çünkü ben hikâyelere politik konuşmalara inandığımdan daha fazla inanıyorum" (Spelling, 2006). Savaş sonrası yıkılan bir şehirden Franco'nun askerlerinin bulunduğu bir karakola sürüklenen Ofelia; annesinin, Vidal'in ya da toplumun istediği birey değil, kendi iç dünyasında olmak istediği kahraman olmak için uğraşır.

Jaromil Jireš'in gerçeklik ve hayal, inanç ve özgürlük, masumiyet ve cinsellik, korku ve zevk gibi karşıt kavramları bir arada işlediği Valerie a Týden Divu da; Alman işgalinden kurtulduktan sonra Stalinist sansürü yaşayan, iki taraf arasında sıkışmış Çekoslovakya halkının yaşadıklarını sembolik bir dille gösterir. Valerie'nin yolculuğu da diğer iki örnekte olduğu gibi toplumun izlerini taşır ve yolculuğun çıkış sebebi de benzer bir şekilde toplumun baskisidir.

Toplumun geçmişi, bugünü ve geleceği olan mitosların her zaman anlatmak istediği bir takım şeyler vardır. Mitosları kurgulayanlar, oluşturdukları bu hikâyelerde deneyimleri ve toplum analizlerini kendi görme biçimleri ile harmanlayıp hayal güçlerini de kullanarak toplumu yansıtmaya çalışırlar. Zaman içerisinde bu çabanın eril söylemin bir aracı haline gelmesi ise mitosu oluşturan kişinin de ideolojik olarak yapılandırılmasından ileri gelir.

Kadın kahramanlar toplumsal cinsiyet kodlarını yıkarak erkeğin dünyasına adım atmak, bu dünyada başarılı olarak kendi ayakları üzerinde durabildiklerini kanıtlamak isterler. Bu bakımdan örneklerdeki kadın kahramanların istediği şey aslında toplumdaki bireylerin de istediği bir şeydir. Ne var ki kadın kahraman yolculuğunun başında erkek kahramandan farklı olarak üzerine yüklenen negatif anlamlardan kurtulması gerektiğini düşünür. Bunu yaparken de aslında erkek ile ilişkilendirilmiş güçlü özelliklerini kadın ile ilişkilendirilmiş zayıf özelliklerine tercih eder. Yolculuğu boyunca aslında kavramları cinsiyet kalıplarına sokarak patriyarkanın eril kodlarını farkında olmadan yeniden üretir. İçindeki dişil yönü geri istemeye başladığında ise onu eril yön ile birleştirerek başarıya ulaşabilir. $\mathrm{Bu}$ noktada kadın kahraman cesur, koruyucu, güçlü bir karakter olmak için erkeğe ya da erkeğin adına ihtiyacı olmadığı, bu kavramların erkeğe değil insanların hepsine ait olduğunu farkına varır. 
Siyasal ve sosyo-kültürel anlamda dönemin şartları ile harmanlanan üç filmde de kadın kahramanların çıktıkları yolculuklar "kadın kahramanın yolculuğu" evrelerini yerine getirir. Her biri kendi kültürel kodları ile bu yolculuğu tamamlasa da şablon, arketipler ve yolculuğun içerisinde barındırdığı mitler benzerlik gösterir. Kadın kahramanın yolculuğu içsel dönüşüm ve deneyim kazanma ile ilgilidir. Kadın kahraman, hayatı boyunca süren bu yolculuğunda kendisini kanıtlayarak başarıya ulaşır. Çevresindeki insanlar ona iyi ya da kötü etkide bulunabilir. Fakat kadın kahramanın başarması gereken ana şey erkek kahraman gibi gücünü kanıtlamak değil, içsel gelişimini tamamlamaktır. Bu yüzden de kadın kahramanın yolculuğu tek seferlik değil, ömür boyudur. Yolun sonunda Alice, Ofelia ve Valerie başarılarından elde ettikleri deneyimleri ile yeni bir yolculuğa başlarlar. Alice Wonderland'den çıkarak kendi gerçekliğine döner ve babasının izinden giderek kadınların ait olmadığı düşünülen ticaret dünyasına adım atar. Ofelia yeraltı dünyasında ailesi ile buluşur ve Prenses Moanna olarak başka bir gerçeklikte başka bir yolculuğa başlar. Valerie'de ailesine kavuşur ve filmin sonunda Gracián (Jan Klusák) gibi kötüler cezalandırılır. Onu da bambaşka bir yolculuk beklemektedir.

Fantastik anlatılarda çeşitli zorluklarla başa çıkan kahramanların yol boyunca yaşadıkları tüm zorluklar mükâfatlandırılır. Kötü ve iyi arasındaki mücadelenin konu alındığı bu anlatı tarzına sahip hikâyeler ya da mitlerin geneli mutlu sonla biter. Bu mutlu sonlar ise okuyuculara, dinleyicilere ya da izleyicilere kötülük karşısındaki çabaların anlamsız olmadığı, her geçen gün daha da kötüye giden dünyanın çaba gösterildiği sürece iyileşebileceği izlenimini uyandırır.

\section{Kaynakça}

Aşcı, D. (2019). Reklamlarda Bağımsız Kadın Temsiline Eleştirel Bir Yaklaşım: 8 Mart Dünya Emekçi Kadınlar Günü Reklamlarının Marksist Feminist Analizi. Mehmet Yakın (Ed.), Reklamı okumak, reklamı anlamak içinde (s. 43 - 74). İstanbul: Urzeni Yayınevi.

Atay, A. (2019). Feminist Kuram Bağlaminda Masallarda Toplumsal Cinsiyet. 5. Uluslararası İletişim Öğrecileri Sempozyumu E-kitabı, 261-267.

Becka, J. (Yapımc1), Jireš, J. (Yönetmen). (1970). Valerie a Týden Divu [Film]. Çekoslovakya: Barrandov Stüdyoları.

Cavarero, A. (1995). In Spite Of Plato. New York: Routledge.

Cuarón, A.; del Toro, G.; Navarro, B.; Torresblanco F. (Yapımcılar), del Toro, G. (Yönetmen). (2006). El Laberinto del Fauno [Film], İspanya: Wild Bunch.

Dunn Mascetti, M. (2000). İçimizdeki Tanrıça: Kadınlığın Mitolojisi. B. Çorakçı (çev.). İstanbul: Doğan Kitapçılık.

Ekinci, A. (23 Mart 2010). "Hepimizin İçinde Bir Alice Var". Hürriyet Kelebek, Erişim adresi: $\quad$ http://www.hurriyet.com.tr/kelebek/hepimizin-icinde-bir-alice-var-14189731 Erişim tarihi: 7 Mart 2019.

Erhat, A. (2011). Mitoloji Sözlüğü. İstanbul: Remzi Kitabevi.

Freud, S. (1998). Totem ve Tabu I. N. Berkes (çev.). İstanbul: Yeni Gün Haber Ajans1 Basin ve Yayıncilık. 
Freud, S. (2014). Psikanalize Giriş: Rüya. A.C. İdemen (çev.). İstanbul: Cem Yayınevi.

Indick, W. (2011). Senaryo Yazarlar İçin Psikoloji. E. Yılmaz \& Y. Karaarslan (çev.). İstanbul: Can Matbaacilik.

Jung, C. G. (2006). Analitik Psikoloji. E. Gürol (çev.). İstanbul: Payel Yayınları.

Kabadayı, L. (2014). Film Eleştirisi: Kuramsal Çerçeve ve Sinemamızdan Örnek Çözümlemeler. İstanbul: Ayrıntı Yayınları.

Murdock, M. (1990). The Heroine's Journey. Massachusetts: Shambhala Publications, Inc.

Özdoyran, G. (2019). John Berger'de Bakış, Kadın Temsili ve Reklam: Bir İmge Nasıl Okunur? Mehmet Yakın (Ed.), Reklamı okumak, reklamı anlamak içinde (s. 43 - 74). İstanbul: Urzeni Yayınevi.

Rank, O. (2001). Doğum Travması. S. Yücesoy (çev.). İstanbul: Metis Yayıncılık.

Roth, J. (Yapımc1), Burton, T. (Yönetmen). (2010). Alice in Wonderland [Film]. ABD: Walt Disney Pictures.

Smelik, A. (2008). Feminist Sinema ve Film Teorisi: ve Ayna Çatladı. D. Koç (çev.). İstanbul: Agora Kitaplığ1.

Spelling, I. (25 Aralık 2006). "Guillermo del Toro and Ivana Baquero escape from a civil war into the fairytale land of Pan's Labyrinth". Erişim Adresi: ftp://asavage.dyndns.org/Literature/scifi.com/www.scifi.com/sfw/interviews/sfw14471. html Erişim tarihi: 7 Mart 2019.

Tanpolat, C. (2016, Ağustos). Doğu ve Batı Kültürlerinde Başlıca Hayvan Mitleri. (Yüksek Lisans Tezi). İstanbul: Işı1k Üniversitesi.

Tecimer, Ö. (2006). Sinema: Modern Mitoloji. İstanbul: Plan B.

Türk Dil Кититu. (b.t.). Türk Dil Kurumu: Erişim adresi: http://www.tdk.gov.tr/index.php?option=com_bts\&view=bts\&kategori1=veritbn\&kelimes ec=114524 Erişim tarihi: 15 Mart 2019.

Woolf, V. (1966). Professions for Women. Collected Essays (s. 284 - 289). New York: International Labour Office. 